\title{
Fixtures Design for Increasing of Quality Production of Cast Workpiece with Weld Deposit
}

Peter Pavol Monka ${ }^{1,3}$, Jaromír Markovič ${ }^{2}$, Katarina Monkova ${ }^{1}$, Jan Řehoř ${ }^{3,4}$, Slavomír Hric ${ }^{1}$, Dušan Mandulák ${ }^{5}$

${ }^{1}$ Technical University of Košice, Faculty of Manufacturing Technologies with seat in Prešov, Bayerova 1, 08001 Prešov, Slovakia. E-mail: peter.monka@tuke.sk, katarina.monkova@tuke.sk, slavomirhric@gmail.com

${ }^{2}$ Slovak Metrological Society, Hviezdoslavova 1124/31, 97401 Banská Bystrica, Slovakia. E-mail: slm@slm.sk

${ }^{3}$ Regional Technological Institute, University of West Bohemia, Univerzitní 8, 30614 Pilsen, Czech Republic. E-mail: monka@rti.zcu.cz, rehor4@rti.zcu.cz

${ }^{4}$ Department of Machining Technology, University of West Bohemia, Univerzitní 22, 30614 Pilsen, Czech Republic. Email: rehor4@kto.zcu.cz

51. Prešovská nástrojáreň, Ltd., L'ubochnianska 2407/2, 08006 Prešov, E-mail: mandulak@1pn.sk

The article deals with the principles of fixtures design and their application at machining of armature DM 100, PN 25/40-RF. It is bulky component that is produced by casting technology. Surfaces near the hole of valve are hard machinable due to weld deposit. Considering elimination of clamping device weaknesses that could originate due to unsuitable design and production, it is advantageous to use a virtual model along with simulation and analysis in CAD/CAM system. Nowadays technologists have strong tools in their hands that increase efficiency of solution not only conventional, but also specific, problems. On the other hand, they have to know to solve some difficulties in their mind, such are, for example, the differences in specifications of coordinate systems used for virtual model in CAD/CAM system and coordinate systems used in real production. The problems can arise in case of cutting tool definition according to the tool-in-hand or tool-in-use systems. Based on theoretical know-how two fixtures were designed for manufacturing of two sets of surfaces that are normal each other, so after inovation manufacturing operations were realized in vertical and in horizontal position of workpiece axes. Using new approach, the production efficiency and production rate have increased twice and no failure product has been made.

Keywords: Design Principles, Jig and Fixture, Hard-Machinable Surface, Virtual Model, Cutting Tool, Coordinate System

\section{Acknowledgment}

The paper was published thanks to the grants VEGA 1/0614/15; KEGA 087TUKE-4/2015; KEGA 013TUKE-4/2014 with direct support of Ministry of Education of the Slovak Republic and thanks to project ED2.1.00/03.0093 - Regional Technological Institute - RTI covered by the European Regional Development Fund and the state budget of the Czech Republic.

\section{References}

[1] ANTIĆ, A. et al (2013) Influence of tool wear on the mechanism of chips segmentation and tool vibration In: Tehnicki Vjesnik, Vol. 20, 1, pp. 105 - 112

[2] ČESÁKOVÁ, I., ZETEK, M., ŠVARC, V. (2014) Evaluation of cutting tool parameters In: Procedia Engineering, Vol. 69, pp. $1105-1114$

[3] HOSNEDL, S. (2014) Theory based management and software support of property driven designing of technical products In: MM Science Journal, Vol. 10, pp. 496 - 502

[4] JURKO, J., PANDA, A., BEHUN, M. (2013) Prediction of a new form of the cutting tool according to achieve the desired surface quality, Appl. Mech. Mat., pp. 268-270.

[5] KROLCZYK, G.M. et al (2015) Determination of tool life and research wear during duplex stainless steel turning In: Source of the Document Archives of Civil and Mechanical Engineering, pp. 473-476

[6] KROLCZYK, J.B. et al (2015) Material flow optimization-a case study in automotive industry In: Tehnicki Vjesnik, 22 (6), pp. 1447-1456

[7] MAJSTOROVIC, V.D. et al (2015) Development of a knowledge base for the planning of prismatic parts inspection on CMM In: Acta IMEKO, Vol. 5, No 2, pp. 10 - 17

[8] MAlOTOVA, S., CEP, R., CEPOVA, L. et al (2016) Roughness Evaluation of the Machined Surface at Interrupted Cutting Process In: Manufacturing Technology, Volume 16, Issue 1, Pages 168-173

[9] METELSKI, A. et al. (2015) Taguchi design of experiment versus dynamic programming approach in the optimization of turning process In: Applied Mechanics and Materials, ISSN 1662-7482, Vol. 808, pp 66-71 
[10] MONKA, P. (2001) Turning tool geometric characteristics identification from machined surface roughness point of view - Doctoral Thesis (In Slovak language), Technical University of Kosice, 158 pp. and 173 pp.

[11] PATEK, M. et al (2014) Non-destructive testing of split sleeve welds by the ultrasonic TOFD method In: Manufacturing Technology, Volume 14, Issue 3, pp. 403-407

[12] PETRU, J. et al (2013) Influence of cutting parameters on heat-affected zone In: Technical Gazette Vol. 20/2, pp. 225-230

[13] PILC, J., VASILKO, K. (2013) Development and applications of a rotating turning tool In: Manufacturing Technology, Volume 13, Issue 2, pp. 226-231

[14] SENVAR, M. O., VAYVAY, O., KURT, E., et al. (2014) Prioritization of balanced scorecard measurement indicators as a process management approach via fuzzy AHP: case study in automotive industry, Technical Gazette, 21, pp. 155-162.

[15] SADILEK, M. et al (2011) Aspects of using tool axis inclination angle, Technical Gazette, 57, pp. 681-688.

[16] STOJADINOVIC, S.M., MAJSTOROVIC, V.D. (2014) Developing engineering ontology for domain coordinate metrology, In. FME Transactions, vol. 42(3), pp. 249-255

[17] UNGUREANU, M. et al. (2015) Product Innovation Management for Business Development In. Proceedings 5th Central European Conference in Regional Science (CERS), pp. 1112 - 1118

[18] VASILKO, K., PILC, J. (2013) New technological knowledge of the rotary turning tool, In: Manufacturing Technology, Volume 13, Issue 4, pp. 571-575 